Acta vet. scand. $1981,22,566-577$.

From the Department of Food Hygiene, College of Veterinary Medicine, Helsinki, Finland.

\title{
SURVIVAL OF CAMPYLOBACTER JEJUNI/COLI IN GROUND REFRIGERATED AND IN GROUND FROZEN BEEF LIVER AND IN FROZEN BROILER CARCASSES
}

\author{
By \\ Marja-Liisa Hänninen
}

\begin{abstract}
HÄNNINEN, MARJA-LIISA: Survival of Campylobacter jejuni/coli in ground refrigerated and in ground frozen beef liver and in frozen broiler carcasses. Acta vet. scand. 1981, 22, 566 - 577. - Survival of 5 strains of Campylobacter jejuni/coli in ground beef liver stored at $4^{\circ} \mathrm{C}$ and at $-20^{\circ} \mathrm{C}$ was studied. After 6 days of storage at $4^{\circ} \mathrm{C}$ the beef liver was spoiled, which was indicated by APC $\log 7.25$ and lactobacilli count $\log$ 7.0. During this storage Campylobacter counts decreased only slightly. After 12 weeks of storage at $-20^{\circ} \mathrm{C}$ Campylobacter counts decreased by $2-3 \operatorname{logs}$ in frozen ground beef liver. Survival of 4 strains of $\mathrm{C}$. jejuni/coli on frozen broiler carcasses was also studied. Two inoculation levels, $10^{3}-10^{4} / \mathrm{g}$ and $10^{4}-10^{5} / \mathrm{g}$ were used. On frozen broiler carcasses Campylobacter counts decreased by $0.5-2.0 \operatorname{logs}$ during 12 weeks at $-20^{\circ} \mathrm{C}$.

C. jejuni; refrigerated storage; frozen storage; beef liver; broiler chicken.
\end{abstract}

Campylobacter jejuni/coli is a common inhabitant of the gut of healthy poultry, wild birds, swine, sheep and cattle (Smibert 1978), which has been known since 1946 to cause human gastroenteritis (Levy 1946). C. jejuni/coli often seems to be harboured in the caecum of broiler chickens (Bruce et al. 1977, Grant et al. 1980, Hänninen \& Raevuori 1981, Persson 1981) or in chicken carcasses (Smith \& Muldoon 1974, Bruce et al.). Of the samples studied by different authors, $1-68 \%$ of chicken caecal contents and $1.8-62 \%$ of chicken carcasses were positive. Bovine bile has also been shown to be a source of campylobacters (Bryner et al. 1964). The bacteria tolerate $10-30 \%$ bovine bile in the cultivation medium (Schneider \& Morse 1955). 
Foods of animal origin, especially milk (Levy 1946, Robinson et al. 1979, Taylor et al. 1979) and poultry (Brouwer et al. 1979), have been suspected of acting as vehicles in certain foodborne epidemics. The tolerance of $\mathrm{C}$. jejuni/coli for the additives used for food preservation is not known, but they are sensitive to $\mathrm{NaCl}$ (Hänninen 1981). They do not grow at room or refrigeration temperatures (Smibert 1974), but they have been shown to survive in water, human urine and milk (Blaser et al. 1980). In general the survival of $\mathrm{C}$. jejuni/coli in different foods and under different storage conditions is poorly known.

The present study was undertaken to determine the effect of refrigeration at $4^{\circ} \mathrm{C}$ and frozen storage on the survival of $\mathrm{C}$. jejuni/coli strains isolated from animals and man in raw ground beef liver and broiler carcasses.

\section{MATERIALS AND METHODS}

\section{Bacterial strains and media}

The C. jejuni/coli cultures used in this study were isolated from bovine (N149), chicken (B42), ovine (L69) and porcine (S17) gut (Hänninen \& Raevuori 1981). Strains 5616 and 6407 were isolated from human gastroenteritis by $T$. Kosunen, Department of Bacteriology and Immunology, University of Helsinki. After isolation, the strains were stored frozen at $-20^{\circ} \mathrm{C}$. For the inoculation of beef liver and chicken carcasses, the strains were transferred to fresh Brucella broth (Difco) and incubated microaerophilically $\left(\mathrm{N}_{2} 85 \%, \mathrm{CO}_{2} 10 \%, \mathrm{O}_{2} 5 \%\right)$ at $35^{\circ} \mathrm{C}$ for $42-48 \mathrm{~h}$. In the refrigeration studies, strains L69, B42, S17, N149 and 6407 were used. In the studies of frozen beef liver and broiler carcasses, the strains used were L69, B42, S17, 5616 and 6407.

For colony counts of $\mathrm{C}$. jejuni/coli a modification of the medium developed by Skirrow (1977) was used, containing $5 \%$ calf blood instead of horse blood. The plates were incubated microaerophilically at $42^{\circ} \mathrm{C}$ for 2 days. As a dilution fluid, $0.1 \%$ peptone water was used.

\section{Inoculations and cultivations}

a. B e e f liver. Fresh beef liver was purchased from an abattoir, ground aseptically soon after delivery and divided into sterile glass blender jars, approximately 600 g per jar. For inoculation, $20 \mathrm{ml}$ of a Brucella broth culture of a $\mathrm{C}$. jejuni/coli strain 
was mixed thoroughly with the ground liver. The inoculation level used was $10^{5}-10^{6}$ cells per $g$ of liver. The glass jars were stored at $4^{\circ} \mathrm{C}$ covered with aluminium foil for survival studies at refrigeration temperature.

For the study of survival of C. jejuni/coli in frozen beef liver, the samples were prepared and inoculated similarly as above. The inoculated ground liver was divided into 12 portions of $50 \mathrm{~g}$ each, which were packed aseptically in polyethene plastic bags and stored frozen at $-20^{\circ} \mathrm{C}$.

In the survival studies at $4^{\circ} \mathrm{C}$, two $10 \mathrm{~g}$ samples were taken from the ground liver for colony counts of campylobacters before inoculation, after inoculation and daily during 6 days. The samples were homogenized with $90 \mathrm{ml}$ of $0.1 \%$ peptone water for $30 \mathrm{~s}$. Tenfold dilutions were made in $90 \mathrm{ml}$ peptone water, and $0.1 \mathrm{ml}$ of each dilution was spread on modified Skirrow medium. The incubation of the plates took place as described above. The $\mathrm{pH}$ of the liver was measured and an organoleptic evaluation was made daily during the study.

In addition, aerobic plate count (Plate Count Agar, $30^{\circ} \mathrm{C} /$ $72 \mathrm{~h}$ ) and counts of lactobacilli (Selective Lactobacillus Agar, $30^{\circ} \mathrm{C} / 5$ days) coliform bacteria (Violet Red Bile Agar, $35^{\circ} \mathrm{C} /$ $24 \mathrm{~h}$ ) and faecal streptococci (Slanetz Bartley Agar, $35^{\circ} \mathrm{C} / 48 \mathrm{~h}$ ) were performed on the day of inoculation and on the 3rd and 6th day of storage. All the media were from Orion Diagnostica, Finland.

The survival of $\mathrm{C}$.jejuni/coli in frozen beef liver was examined after storage for $0,3,6$ and 12 weeks. Two $50 \mathrm{~g}$ samples of the liver were thawed at $4^{\circ} \mathrm{C}$. A $10 \mathrm{~g}$ sample of each $50 \mathrm{~g}$ portion was analyzed for Campylobacter as described in the survival studies at $4^{\circ} \mathrm{C}$. The samples were also analyzed for aerobic plate count (APC) and coliform bacteria. The remaining portions of $40 \mathrm{~g}$ were kept at $4^{\circ} \mathrm{C}$ for 2 days and analyzed for Campylobacter as before.

b. Broiler carcasses. Frozen broilers were purchased from a local retail store and thawed at $4^{\circ} \mathrm{C}$ overnight. Each carsass was divided into 5 portions. Prior to inoculation, Campylobacter cultivation was carried out from the skin for the detection of possible natural contamination. Each portion was then dipped for 3 min in a mixture of Brucella broth and peptone water $(1: 3)$, to which the strain of $\mathrm{C}$. jejuni/coli in question was added. The number of Campylobacter cells in the dipping fluid 
was adjusted to approximately either $10^{5}-10^{6}$ cells per $\mathrm{ml}$ or $10^{3}-10^{4}$ cells per ml. After inoculation the portions were packed individually in polyethene plastic bags and stored at $-20^{\circ} \mathrm{C}$. Two inoculated samples for each of the Campylobacter strains studied were examined immediately after dipping by taking a $10 \mathrm{~g}$ sample of the skin, which was analyzed for the initial count of $\mathrm{C}$. jejuni/coli as described in the survival studies at $4^{\circ} \mathrm{C}$. After storage for 3, 6, 9 and 12 weeks, the 2 bags were thawed for $12 \mathrm{~h}$ at $4^{\circ} \mathrm{C}$, and 1 sample of $10 \mathrm{~g}$ from the skin and 1 sample of $1 \mathrm{ml}$ from the drip of both bags were taken for the Campylobacter count. The thawed samples were stored at $4^{\circ} \mathrm{C}$ for 2 days and Campylobacter counts were again made from the skin and drip.

\section{RESULTS}

Refrigerated storage of ground beef liver

The survival of 5 Campylobacter strains, the log numbers of aerobic bacteria, lactobacilli, coliform bacteria and faecal streptococci, and the changes in $\mathrm{pH}$ value during 6 days of storage of ground raw beef liver at $4^{\circ} \mathrm{C}$ are presented in Table 1 . The storage of ground beef liver at refrigeration temperature had no effect on the survival of $\mathrm{C}$. jejuni/coli strains over the study period. The log number of Campylobacter cells decreased only

Table 1. Log numbers per g (mean $\pm s$ ) of Campylobacter jejuni/ coli, aerobic plate count, faecal streptococci, coliform bacteria and lactobacilli as well as changes of $\mathrm{pH}$ value in ground beef liver stored at $4{ }^{\circ} \mathrm{C}$ for 6 days.

\begin{tabular}{llllllllll}
\hline & & \multicolumn{10}{c}{ Days of storage } \\
\cline { 3 - 9 } & $\mathrm{N}^{1}$ & & 0 & 1 & 2 & 3 & 4 & 5 & 6 \\
\hline Strain of C. jejuni/coli & & & & & & & & & \\
$\quad$ L69 & 2 & 5.55 & 5.52 & 5.45 & 5.16 & 5.70 & 5.51 & 5.25 \\
$\quad$ S17 & 2 & 5.85 & 5.92 & 5.61 & 5.67 & 5.75 & 5.68 & 5.60 \\
$\quad 6407$ & 2 & 6.30 & 6.30 & 6.11 & 5.97 & 5.64 & 5.99 & 5.90 \\
$\quad$ B42 & 2 & 6.19 & 6.00 & 6.10 & 5.90 & 5.80 & 5.62 & 5.90 \\
$\quad$ N149 & 2 & 6.30 & 6.60 & 6.30 & 6.30 & 6.25 & 6.00 & 6.30 \\
Aerobic plate count & 6 & $5.87 \pm 0.05$ & - & - & $6.77 \pm 0.02$ & - & - & $7.25 \pm 0.07$ \\
Faecal streptococci & 6 & $3.55 \pm 0.45$ & - & - & $3.72 \pm 0.60$ & - & - & $4.05 \pm 0.06$ \\
Coliform bacteria & 6 & $2.90 \pm 0.10$ & - & - & $3.20 \pm 0.24$ & - & - & $3.25 \pm 0.13$ \\
Lactobacilli & 6 & $4.40 \pm 0.10$ & - & - & $6.02 \pm 0.10$ & - & - & $7.00 \pm 0.04$ \\
pH & & 6.35 & 6.30 & 6.30 & 6.00 & 5.90 & 5.80 & 5.75 \\
\hline
\end{tabular}

1 number of samples. 
slightly. During 6 days of storage the aerobic count increased about $1.4 \mathrm{logs}$, indicating mainly the growth of psychotrophic organisms. The lactobacilli count increased about 2.6 logs, indicating that Gram-positive lactic acid bacteria are able to grow in ground beef liver at refrigeration temperature and that they form the dominant species in liver spoilage. Analysis for Campylobacter was not carried out after 6 days, since the samples had deteriorated so much as to be unfit for human consumption.

During the observation period the $\mathrm{pH}$ value decreased from 6.3 to 5.75. The liver was evaluated as organoleptically sour on the 5th day of storage.

The count of faecal streptococci increased only slightly during 6 days and the count of coliform bacteria remained unchanged.

\section{Frozen storage of ground beef liver}

The results concerning the survival of $\mathrm{C}$. jejuni/coli in frozen ground beef liver are shown in Fig. 1. The inoculation levels used were $\log 6.53-6.75$ per $\mathrm{g}$ of liver. The Campylobacter counts decreased during storage of 12 weeks by $2-3$ logs. The counts decreased most considerably during the initial days of storage, when approximately $90 \%$ of the Campylobacter became unviable. The mean aerobic plate count was $\log 4.87 \pm 0.15$, the

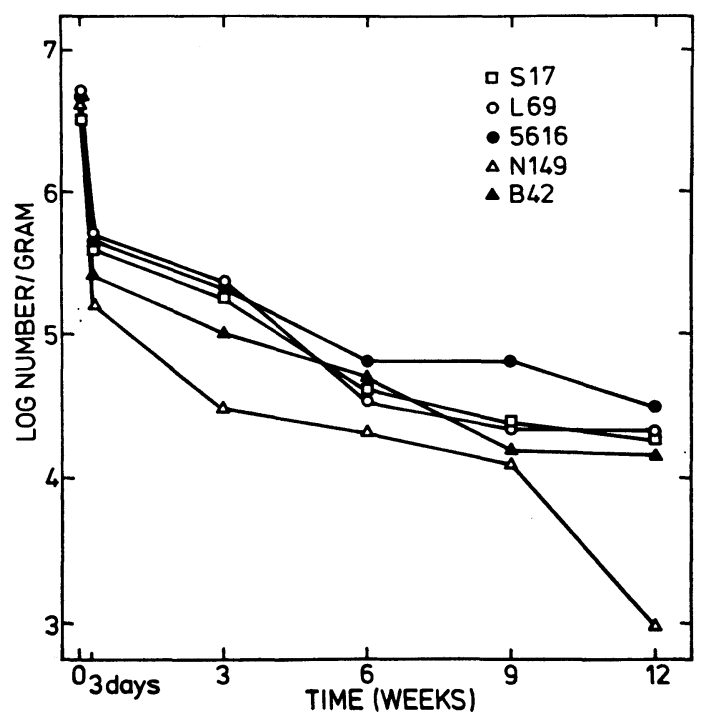

F i g u r e 1. Survival of C. jejuni/coli strains (S17 $\square$, L69 $\bigcirc, 5616$, $\mathrm{N} 149 \triangle$, and B42 $\triangle$ ) in ground beef liver at $-20^{\circ} \mathrm{C}$ for 12 weeks. 
mean coliform count $\log 2.50 \pm 0.36$ and $\mathrm{pH}$ value $6.3 \pm 0.1$ in the samples taken during the experimental period.

The influence of thawing and subsequent storage on the Campylobacter count is presented in Table 2. After 2 days of storage of the thawed samples at $4^{\circ} \mathrm{C}, 60-70 \%$ of the organisms were viable.

\section{Frozen storage of broiler carcasses}

The survival of Campylobacter strains on the skin and in the drip is shown in Figs. 2a and 2b. For the chicken strain B42 and for the human strains 2 different inoculation levels were used, indicating high and low initial contamination level. During the experimental period of 12 weeks, Campylobacter counts of all strains decreased both in skin samples and in those of drip. The decrease for animal strains was about 2 logs in both the skin and the drip samples at the higher contamination level. The human strains 5616 and 6407 were less affected by storage. The decrease in the Campylobacter count was less than $0.5 \mathrm{log}$ in both the skin and the drip samples for strain 5616. The cell counts of strain 6407 decreased by about 0.5 and $1 \log$, respectively. The Campylobacter counts during the whole study period were higher in all the drip samples than in the skin samples.
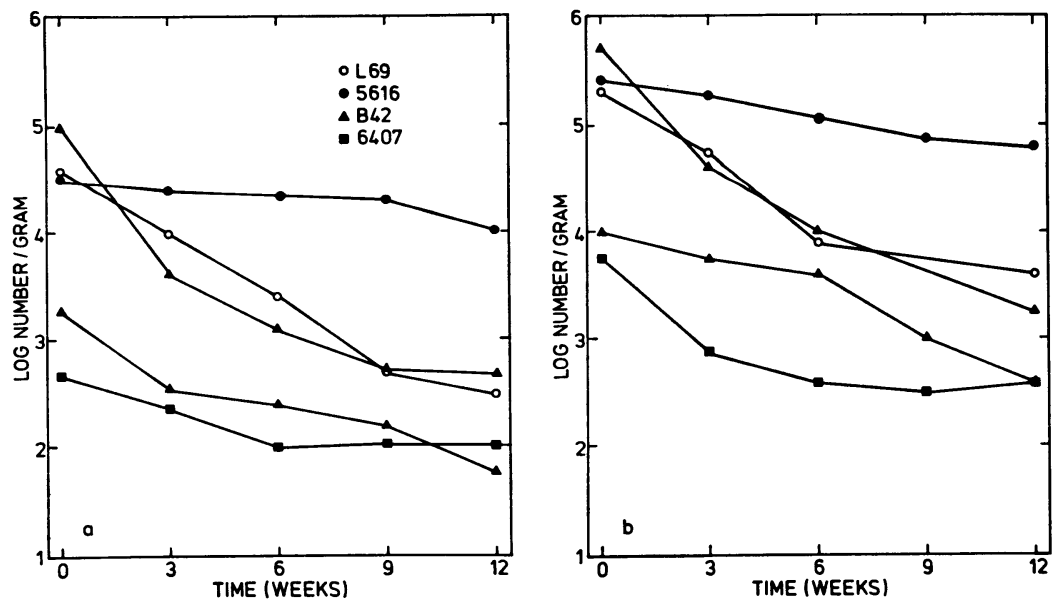

F i g u r e 2 a (left). Survival of C. jejuni/coli strains (L69 $\bigcirc, 5616$, B42 $\triangle$, and $6407 \square$ ) on skin samples of broilers at $-20^{\circ} \mathrm{C}$ for 12 weeks.

F i g u r e 2 b (right). Survival of C. jejuni/coli strains (L69 O, 56160, $\mathrm{B} 42 \triangle$, and 6407 $\square$ ) in the drip of broilers at $-20^{\circ} \mathrm{C}$ for 12 weeks. 
T a b le 2. The effect of thawing and subsequent storage for 2 days at $4^{\circ} \mathrm{C}$ on the count of $\mathrm{C}$. jejuni/coli in ground beef liver and broiler carcasses.

\begin{tabular}{|c|c|c|c|c|c|}
\hline \multirow[b]{2}{*}{ Strain } & \multirow[b]{2}{*}{$\mathrm{N}^{2}$} & \multicolumn{4}{|c|}{$\begin{array}{l}\text { Means and standard deviations }(\dot{r}) \text { of the differences } \\
\text { between the } \log \text { numbers } / \mathrm{ml} \text { of Campylobacter cells }{ }^{1}\end{array}$} \\
\hline & & Ground beef liver & $\mathbf{N}^{2}$ & $\begin{array}{l}\text { Broiler ca } \\
\text { skin }\end{array}$ & drip \\
\hline 5616 & 3 & $0.38 \pm 0.10$ & 6 & $0.28 \pm 0.19$ & $0.28 \pm 0.17$ \\
\hline L69 & 3 & $0.25 \pm 0.13$ & & & \\
\hline B42 & 3 & $0.35 \pm 0.07$ & & & \\
\hline S17 & 3 & $0.17 \pm 0.22$ & & & \\
\hline N149 & 3 & $0.45 \pm 0.48$ & & & \\
\hline
\end{tabular}

$1 \log$ number of Campylobacter cells immediately after thawing $\log$ number of Campolybacter cells after storage of samples at $4^{\circ} \mathrm{C}$ for 2 days.

2 number of samples.

After 2 days of storage of samples at $4^{\circ} \mathrm{C}$ a roughly $50 \%$ of the Campylobacter were unviable. This analysis was made only for the human strain 5616. The results are presented in Table 2.

\section{DISCUSSION}

\section{Refrigerated storage of beef liver}

During evisceration, beef liver can be contaminated by intestinal bacteria such as Salmonella or other intestinal pathogens (Kampelmacher 1963). As of today no report has been published indicating the contamination rate of beef carcasses or liver by bovine intestinal $\mathrm{C}$. jejuni/coli. The contamination rate should be low, according to the results obtained in a survey where approximately $4 \%$ of 200 bovine faecal samples examined were positive (Hänninen \& Raevuori 1981). There is only one reference in which raw beef liver is suspected as the vehicle in human Campylobacter infection (Soonattrakul et al. 1971).

The Campolybacter strains examined survived well in ground beef liver at refrigeration temperature. The contamination levels used were very high compared to the natural contamination level, which apparently, as has been proven with other enteric pathogens such as Salmonella (Ayres et al. 1980), is quite low. Although the ground beef liver was stored normally in air, not microaerophilically, this had no effect on Campylobacter survival. The low storage temperature seems to be advantageous for 
Campylobacter, as has been confirmed also by in vitro studies (Blaser et al. 1980). The reason for this is probably the fact that the resting cells are not so sensitive to external stress factors as are cells near or at the cell growth temperature.

In this experiment the growth of spoilage flora, faecal contamination indicator organisms, $\mathrm{pH}$ and organoleptic changes in beef liver were also followed. Due to the high glycogen content of liver the predominant species in spoilage have been shown to be lactic acid bacteria, rather than Gram-negative rods as in the usual spoilage of meat (Sheleff 1975). The growth of lactobacilli did not seem to have any antagonistic effect on Campylobacter under the conditions of the experiment, although the lactobacilli used as food starter cultures usually do have a strong antagonistic effect on Gram-negative food-borne pathogens (Hurst 1973).

When the beef liver begins to spoil, the $\mathrm{pH}$ falls below 6.0 due to growth of lactobacilli (Sheleff). The $\mathrm{pH}$ fall had no effect on the Campylobacter count. It has been shown in vitro that a $\mathrm{pH}$ over 3.5 in a microbiological culture medium does not inhibit the survival of C. jejuni/coli (Blaser et al.).

Frozen storage

B e ef liver. Beef liver is commonly stored frozen. If it is contaminated by a Campylobacter strain pathogenic for man, this will, as the present study indicates, survive the freezing and thawing process. There is, however, usually no risk of food-borne Campylobacter enteritis, since cooking easily kills the bacterium. The theoretical risk occurs during the thawing of the frozen liver, by cross-contamination of raw salads or other uncooked foods. The Campylobacter seems to behave as typical Gram-negative bacteria in frozen foods; the freezing process decreases bacterial viability (Ingram 1951). The present work shows that the most sudden killing of Campylobacter occurs at the beginning of frozen storage, probably during the freezing process.

It has been shown, e.g. with Y. enterocolitica (Hanna et al. 1977), that beef inoculated with $10^{8.5}$ cells/g had, after 28 days of frozen storage, about 10 viable cells/g. It has also been confirmed that high-temperature mesophiles are more sensitive to the lethal effect of freezing than low-temperature mesophiles (Farrell \& Rose 1967).

The effect of the freezing temperature during the freezing 
process is of importance for microbial survival, lower temperatures being less deleterious than higher ones (Ayres et al. 1980). The freezing temperature used in this study was lower, but the storage temperature was the same as that commonly used in food industry. Beef liver is recommended to be stored frozen no more than 4 months at $-17.8^{\circ} \mathrm{C}$ (Tressler 1960). The present study has shown that 3 months frozen storage is not enough to destroy all campylobacters, if the contamination level is high.

B r o ile r c a r casses. Cross contamination of poultry carcasses by intestinal C. jejuni/coli can easily occur during slaughtering and processing, especially during cold water chilling. It has recently been shown that $\mathrm{C}$. jejuni/coli resists the processing conditions of poultry slaughter, including the chlorination of water (Simmons \& Gibbs 1979). The results of the present study show that Campylobacter will survive the frozen storage of broiler carcasses, although the amount of viable bacteria does decrease considerably. The results are comparable to the results obtained with frozen beef liver.

The results further showed that Campylobacter survives well in thawed poultry at refrigeration temperature before preparation for food. During the thawing process the thawing water can cross-contaminate other foods which are eaten without cooking. The cross-contamination of other foods with $\mathrm{C}$. jejuni/coli is probably not so dangerous as e.g. with Salmonella, since C. jejuni/coli does not grow at normal food handling temperatures. As of now only one large foodborne Campylobacter epidemic has been reported in which broilers have been suspected as the vehicle (Brouwer et al. 1979). An association, however, has frequently been demonstrated in Campylobacter enteritis between the human disease and contact with chickens harbouring the organisms, whether at the farm, in the butcher's shop, or in the home (Blaser et al. 1979). Since the natural contamination level is probably much lower than that used in the present study, the killing effect of freezing on small amounts of bacteria could make them undetectable by present cultivations methods. If food proves to be an important vehicle in Campylobacter infections, more sensitive methods, including enrichment procedures, will have to be developed.

More work is needed to determine which samples from the chicken carcass give the most reliable results in the detection of 
C. jejuni/coli. In the present study, the Campylobacter counts were always somewhat higher in the drip samples than in the skin samples. This may be due either to the attachment procedure of Campylobacter, in that the strains examined did not attach well to the skin, or to the fact that drip is rich in nutrients, has a good buffering capacity and protects the organism from the killing effect of air.

The Skirrow type medium used in the studies proved to be satisfactory in the detection of $\mathrm{C}$. jejuni/coli in foods. The growth of the indigenous flora of foods was not fully inhibited. We have noted that when bacitracin is added to the medium, the growth of certain indigenous bacteria of foods, especially $\alpha$-haemolytic streptococci, is inhibited. The addition of amphotericin $B$, as is recommended (Blaser et al. 1979), inhibits the growth of molds, which are usual in food samples. If fresh moist medium was used for the plating of samples, the colonies had a tendency to spread on the plate and were difficult to count. By drying the plates before cultivation or by raising the agar concentration to $2 \%$ this problem could be avoided. Typically there may be 2 types of Campylobacter colonies on the same plate: one spread out and irregular, the other small, convex and round.

\section{CONCLUSIONS}

The survival of $\mathrm{C}$. jejuni/coli in ground beef liver was not affected by storage of the liver samples at $4^{\circ} \mathrm{C}$ for 6 days. During frozen storage at $-20^{\circ} \mathrm{C}$ of ground beef liver and broiler samples for 12 weeks Campylobacter counts decreased considerably, although they were still detectable after this time. The survival of $\mathrm{C}$. jejuni/coli was better in the drip samples than on the skin samples of broilers. The Skirrow type medium which was used in the detection of C. jejuni/coli was satisfactory. Studies are needed to determine the effectiveness of methods originally developed for the isolation of $\mathrm{C}$. jejuni/coli from stools in the recovery of low numbers of $\mathrm{C}$. jejuni/coli from foods.

\section{REFERENCES}

Ayres, J. C., J. O. Mundt \& W. E. Sandine: Prevention of food spoilage. In: Microbiology of Foods. B. S. Schweigert (ed.). W. H. Freeman and Company, San Francisco 1980, pp. 44-71.

Blaser, M. J., D. Berkowitz, F. M. Laforce, J. Cravens, L. B. Retter \& W. L. Wang: Campylobacter enteritis: Clinical and epidemiologic features. Ann. intern. Med. 1979, 91, 179-185. 
Blaser, M. J., H. L. Hardesty \& W.-L. Wang: Survival of Campylobacter fetus subsp. jejuni in biological milieus. J. clin. Microbiol. 1980, 11, 309-313.

Brouwer, R., M. J. A. Merteus, T. H. Siem \& J. Katchaki: An explosive outbreak of campylobacter enteritis in soldiers. Antonie van Leeuwenhoek 1979, 45, 517-519.

Bruce, D., W. Zochowski \& J. R. Rerguson: Campylobacter enteritis. Brit. med. J. 1977, ii, 1219.

Bryner, J. H., P. A. Perry \& A. H. Frank: Vibrio infection of the digestive organs of cattle. Amer. J. vet. Res. 1964, 25, 10481050.

Farrell, J. \& A. Rose: Temperature relationships among micro-organisms. In: Thermobiology. A. Rose (ed.). Academic Press, New York and London 1967.

Grant, I. H., N. J. Richardson \& V. D. Bokkenheuser: Broiler chickens as potential source of Campylobacter infections in humans. J. clin. Microbiol. 1980, 11, 508-510.

Hanna, M. O., J. C. Stewart, Z. I. Carpenter \& C. Vanderzant: Effect of heating, freezing and $\mathrm{pH}$ on $\mathrm{Y}$. enterocolitica-like organisms from meat. J. Food Protect. 1977, 40, 689-692.

Hurst, A.: Microbial antagonism in foods. Canad. Inst. Food Sci. Technol. J. 1973, 6, 80-90.

Hänninen, M.-L.: The effect of $\mathrm{NaCl}$ on Campylobacter jejuni/coli. Acta vet. scand. $1981,22,578-588$.

Hänninen, M.-L.: Characterization of Campylobacter jejuni/coli isolated from different sources. To be published.

Hänninen, M.-L. \& M. Raevuori: Occurrence of Campylobacter fetus subsp. jejuni and Yersinia enterocolitica in domestic animals and in some foods of animal origin in Finland. Nord. Vet.-Med. $1981,33,441-445$.

Ingram, $M$. .: The effect of cold on micro-organisms in relation to food. Proc. Soc. appl. Bact. 1951, 14, 243-250.

Kampelmacher, E. H.: The role of salmonellae in foodborne diseases. In: Microbiological Quality of Foods. L. W. Slanetz et al. (ed.) Academic Press, New York 1973, pp. 84-101.

Levy, A. J.: A gastroenteritis outbreak probably due to a bovine strain of vibrio. Yale J. Biol. Med. 1946, 18, 243-258.

Persson, L.: Förekomsten av Campylobacter fetus subsp. jejuni hos svin och fjäderfä. (The prevalence of Campylobacter fetus subsp. jejuni isolated from swine and fowl). Svensk Vet.-Tid. $1981,33,79-81$.

Robinson, D. A., W. M. Edgar, G. L. Gibson, A. A. Matchett \& L. Robertson: Campylobacter enteritis associated with the consumption of unpasteurised milk. Brit. med. J. 1979, i, 1171-1173.

Schneider, D. W. \& E. V. Morse: The growth and viability of Vibrio fetus and related Vibrios in media containing ox bile. Cornell Vet. $1955,45,84-89$. 
Sheleff, L. A.: Microbial spoilage of fresh beef liver. J. appl. Bact. 1975, 139, 273-280.

Simmons, N. A. \& F. J. Gibbs: Campylobacter spp. in oven-ready poultry. J. Infect. 1979, 1, 159-162.

Skirrow, M. B.: Campylobacter enteritis - a "new" disease. Brit. med. J. $1979, i i, 9$.

Smibert, R. M.: Campylobacter. In: Bergey's Manual of Determinative Bacteriology. Buchanan, R. E. \& N. E. Gibbons (ed.). 8th Ed. Williams \& Wilkins, Baltimore 1974, pp. 207-211.

Smibert, R. M.: The genus Campylobacter. Ann. Rev. Microbiol. 1978, $32,673-709$.

Smith, M. V.\& P. J. Muldoon: Campylobacter fetus subspecies jejuni (Vibrio fetus) from commercially processed poultry. Appl. Microbiol. 1974, 27, 995-996.

Soonattrakul, W., B. R. Andersen \& J. H. Bryner: Raw liver as a possible source of Vibrio fetus septicemia in man. Amer. J. med. Sci. 1971, 261, 245-249.

Taylor, P. R., W. M. Weinstein \& J. H. Bryner: Campylobacter fetus infection in human subjects. Association with raw milk. Amer. J. Med. 1979, 66, 779-783.

Tressler, $D . K$.: Storage life of selected frozen foods. Recommended maximum storage periods for meat. Frozen food almanac. Quick frozen foods. 1960,23, p. 148.

\section{SAMMANFATTNING}

Förekomsten av inokulerade Campylobacter jejuni/coli bakterier, $i$ malen nötlever efter nedkyling eller djupfrysning och $i$ broilers efter djupfrysning.

Fem stammar av C. jejuni/coli inoculerades $\mathrm{i}$ malen nktlever och förekomsten av dessa följdes under 6 dagar i $4^{\circ} \mathrm{C}$ och under 12 veckor i $-20^{\circ} \mathrm{C}$. Efter 6 dagar i $4^{\circ} \mathrm{C}$ var den malna levern fördärvad, vilket manifesterades av totalantalet av bakterier, $\log 7.25$, och av antalet laktobasilli, $\log 7.0$. Under förvaringen av malen lever i $4^{\circ} \mathrm{C}$ blev antalet av Campylobacter celler nästan oförändrad. Efter 12 veckor i -20 $0^{\circ} \mathrm{C}$ minskade antalet av $\mathrm{C}$. jejuni/coli celler med 2 till 3 logs $\mathrm{i}$ malen lever.

Förekomsten av C. jejuni/coli i djupfrysta broiler förvarade i $-20^{\circ} \mathrm{C}$ för 12 veckor undersöktes också. I djupfrysta broilers minskade antalet av C. jejuni/coli celler med 0.5 till 2.0 logs under 12 veckor $\mathrm{i}-20^{\circ} \mathrm{C}$.

(Received October 31, 1981).

Reprints may be requested from: Marja-Liisa Hänninen, the Department of Food Hygiene, College of Veterinary Medicine, Hämeentie 57, 00550 Helsinki 55, Finland. 